\section{SAÚDE E AMBIENTE}

V.8 • N.3 2021 - Fluxo Contínuo

ISSN Digital: 2316-3798

ISSN Impresso: 2316-3313

DOI: 10.17564/2316-3798.2021v8n3p279-293

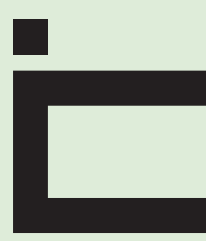

开N开医

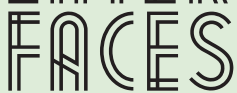

CIENTÍFICAS

\title{
MONITORING OF 2-METHYLISOBORNEOL AND GEOSMINE IN A CONSTRUCTED LAKE TO PUBLIC SUPPLY IN SOUTHERN BRAZIL
}

MONITORAMENTO DE 2-METILISOBORNEOL E GEOSMINA EM UM LAGO CONSTRUIIDO PARA ABASTECIMENTO PÚBLICO NO SUL DO BRASIL

MONITOREO DEL 2-METILISOBORNEOL Y GEOSMINA EN UN LAGO CONSTRUIDO PARA EL SUMINISTRO DE AGUA PÚBLICA EN EL SUR DE BRASIL

Helena Gabriela Wilges ${ }^{1}$ Adilson Ben da Costa ${ }^{2}$

Ênio Leandro Machado ${ }^{3}$

Mariana Maria Gassen Berlt ${ }^{4}$ Jocelene Soares ${ }^{5}$ Marcelino Hoppe ${ }^{6}$

Tiele Medianeira Rizzetti ${ }^{7}$

Andrea Sanchez-Barrios ${ }^{8}$

Rosana de Cassia de Souza Schneider ${ }^{9}$

\section{ABSTRACT}

People that consumed treated water from Dourado Lake, Santa Cruz do Sul, RS, Brazil, perceived alterations in its taste and odor. Based on this, it was studied the monitoring of 2-mthylisoborneol (2-MIB) and geosmin (GSM) in samples collected from Dourado Lake, using solid-phase microextraction (SPME) coupled to gas chromatography/ mass spectrometry (GC/MS). The monitoring was done by performing exploratory evaluations at several points on the lake during the summers of 2017 and 2018 and in all seasons of 2019, considering points of water in an inflow and an outflow of the lake. At the inlet point, the average concentration of GSM was $7.56 \pm 1.94 \mathrm{ng} \mathrm{L}^{-1}$ and that of 2 -MIB was $33.09 \pm 6.89 \mathrm{ng} \mathrm{L}^{-1}$. However, for the outlet point, the average concentrations of GSM and 2-MIB were $10.62 \pm 2.51 \mathrm{ng} \mathrm{L}^{-1}$ and $28.72 \pm 10.47 \mathrm{ng} \mathrm{L}^{-1}$, respectively. In all cases, the presence of GSM and 2-MIB was perceptible by the people consuming the water (during all seasons), showing the need for correct management of water resources.

\section{KEYWORDS}

Dourado Lake, taste, odor, 2-methyl isoborneol, monitoring, geosmin 


\section{RESUMO}

Pessoas que consumiram água tratada da Lagoa Dourado, Santa Cruz do Sul, RS, Brasil, perceberam alterações no sabor e no odor. Com base nisso, foi realizado o monitoramento de 2-metilisoborneol (2-MIB) e geosmina (GSM) em amostras coletadas na Lagoa Dourado, utilizando Microextração em Fase Sólida (MEFS) acoplada a cromatografia gasosa com espectrometria de massas (CG/EM). 0 monitoramento foi feito por avaliações exploratórias em diversos pontos do lago durante os verões de 2017 e 2018 e em todas as estações de 2019, considerando pontos de água no aporte e deságue do lago. No ponto de entrada, a concentração média de GSM foi de 7,56 $\pm 1,94 \mathrm{ng} \mathrm{L}^{-1}$ e de 2-MIB foi de $33,09 \pm 6,89 \mathrm{ng} \mathrm{L}^{-1}$. Porém, para o ponto de saída, as concentrações médias de GSM e 2-MIB foram de $10,62 \pm 2,51 \mathrm{ng} \mathrm{L}^{-1}$ e $28,72 \pm 10,47 \mathrm{ng} \mathrm{L}^{-1}$, respectivamente. Em todos os casos, a presença do GSM e 2-MIB foi perceptível pelas pessoas que consomem água (em todas as estações), evidenciando a necessidade de uma correta gestão dos recursos hídricos.

\section{PALAVRAS-CHAVE}

Lago Dourado. Sabor. Odor. 2-metil Isoborneol. Monitoramento. Geosmina

\section{RESUMEN}

Personas que consumieron agua tratada del Lago Dorado, Santa Cruz do Sul, RS, Brasil percibieron alteraciones en el sabor y en el olor. Con base en eso, se estudió en el monitoreo de 2- metilisoborneol (2-MIB) e geosmina (GSM) en muestras colectadas en el Lago Dorado, utilizando Micro extracción en Fase Sólida (MEFS) acoplada a cromatografía gaseosa con espectrometría de masas (CG/EM). El monitoreo fue hecho por evaluaciones exploratorias en diversos puntos del lago durante los veranos de 2017 y 2018 y en todas las temporadas de 2019, considerando puntos de agua en una entrada y una salida del lago. En el punto de entrada, la concentración media de GSM fue de 7,56 $\pm 1,94 \mathrm{ng} \mathrm{L}^{-1} \mathrm{y}$ de 2-MIB fue de 33,09 $\pm 6,89 \mathrm{ng} \mathrm{L}^{-1}$. Pero, para el punto de salida, las concentraciones medias de GSM y 2-MIB fueron de $10,62 \pm 2,51 \mathrm{ng} \mathrm{L}^{-1}$ y $28,72 \pm 10,47 \mathrm{ng} \mathrm{L}^{-1}$, respectivamente. En todos los casos, la presencia del GSM y 2-MIB fue perceptible por las personas que consumen agua (en todas las temporadas), evidenciando la necesidad de una correcta gestión de los recursos hídricos.

\section{PALABRAS CLAVE}

Lago Dourado, sabor, olor, 2-metil isoborneol, monitoreo, geosmina 


\section{INTRODUCTION}

There are various water quality parameters, but a pair that is quickly recognized by the public is composed of odor and taste, which are defined as low water quality indicators. Volatile compounds generated by harmful algae blooms (HABs) and cyanobacteria blooms (cHABs) potentially explain why these characteristics are present in water, making them a significant problem worldwide. Countries with the highest frequencies of these events are also the most productive in terms of solution development and understanding of the problem, with the USA and China as the main "hot spots" for this type of study (CARMICHAEL; BOYER 2016; JOHN et al., 2018; PALMEIRA et al., 2019).

Tertiary alcohols geosmin (GSM) (1,10-dimethyl-trans-9-decalol) and 2-methylisoborneol (2MIB) cause an unpleasant taste in water, making them a worldwide concern (BRISTOW et al., 2019; PERKINS et al., 2019) because approaches used for water treatment and to ensure water quality are ineffective at removing these compounds (LIU et al.; 2017).

The presence of HABs in water bodies leads to the addition of extra steps to water treatment and an increase in the consumption of bottled water as a consequence of public mistrust-even when the cost of bottled water is higher than tap water (ZAT; BENETTI, 2011). The lack of association between these molecules and any impact on people's health stopped Brazilian authorities from mandating their detection in water (SRINIVASAN; SORIAL, 2011). However, a low odor threshold concentration can easily be perceived by the population (KIM et al., 2016): for 2-MIB, this threshold varies between 4-15 $\mathrm{ng} \mathrm{L} \mathrm{L}^{-1}$, and for GSM it varies from 1 to $10 \mathrm{ng} \mathrm{L^{-1 }}$ (KIM et al., 2016; WATSON et al., 2016; BRISTOW et al., 2019; LI et al., 2019).

Summer conditions lead to increases in HAB and cHAB episodes (VON SPERLING et al., 2008; KUTSCHERA et al., 2009; SRINIVASAN; SORIAL, 2011; PADEDDA et al., 2017). Also, the presence of GSM and 2-MIB is more severe due to variations in temperature, light, and nutrients (WATSON et al., 2016; PADEDDA et al., 2017). In Brazil, detecting these molecules is an issue due to the cost of the methodologies needed, but their detection is important for proper management and the development of strategies to reduce concentrations upstream (WATSON et al., 2000; SUURNÄKKI et al., 2015).

A water body that has already experienced several episodes of HABs is Dourado Lake, an important reservoir for the public water supply in Santa Cruz do Sul, RS, southern Brazil, a municipality of approximately 140,000 inhabitants. The Pardinho River is close to industry, urban centers, and agricultural production, which are responsible for the loss of water quality because they have increased the nutrient load and changed the trophic level of the water (LOBO et al., 2011).

Considering regional problems and the eutrophication events occurring every year in several countries, the objective of this study was to monitor the presence of the main substances that cause taste and odor (GSM and 2-MIB) in the water of Dourado Lake, Santa Cruz do Sul, RS, Brazil. Our study results provide information that allows us to discuss conditions related to previous episodes of HABs and the influence of weather conditions. 


\section{MATERIALS AND METHODS}

\subsection{STUDY AREA}

The study area was Dourado Lake (FIGURE 1), which has a depth of approximately $3 \mathrm{~m}$ and an annual temperature of $20^{\circ} \mathrm{C}$ (average, according to meteorological data from 2004-2019, obtained in the municipality by the meteorological station of the University of Santa Cruz do Sul); it is comprised of multiple sampling points.

\subsection{SAMPLE COLLECTION}

Collection occurred in two stages (seasons/years). First, we collected during summer 2017 and summer 2018 to select the points that would be analyzed in-depth the following year. Second, during 2019, two points in Dourado Lake were sampled (an inlet channel coming from the Pardinho River and an outlet where water was directed to treatment facilities or return to the river course), resulting in a total of 44 samples, with triplicates (FIGURE 1). This reservoir, supplied by the Pardinho River, occupies an area of 119 ha with a capacity for 3 million cubic meters of water.

Surface water was collected (close to the margin) in $500 \mathrm{~mL}$ polyethylene terephthalate packaging during the early hours of the day (8-9 am). Samples were immediately prepared and analyzed, and they were stored in the refrigerator (hermetically sealed headspace glass bottle) for short periods during the analysis.

Figure 1 - Dourado Lake (Santa Cruz do Sul, RS) localization and water sampling points

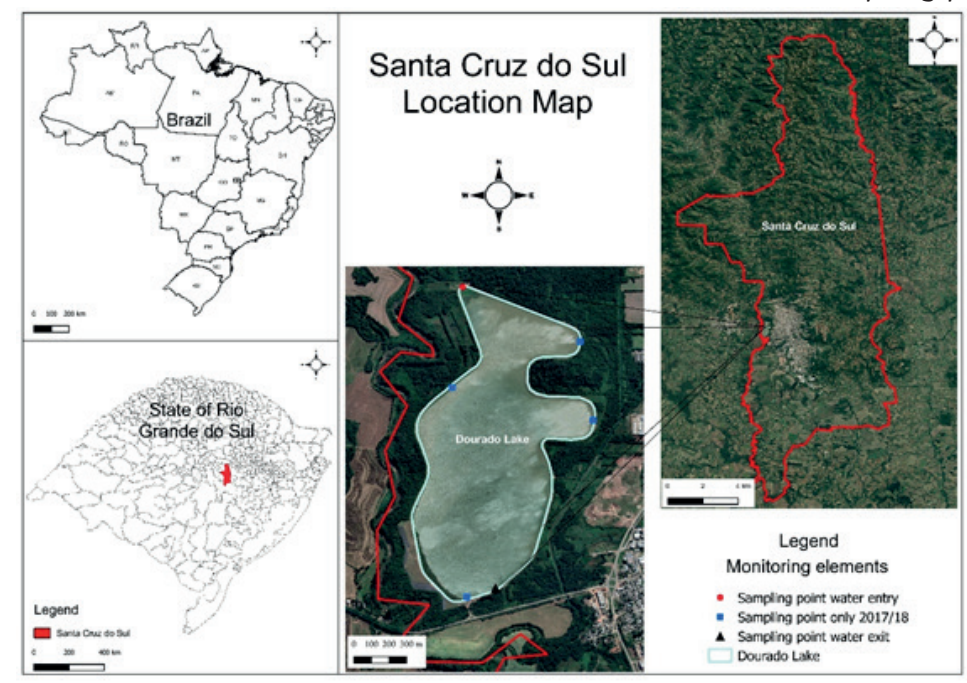

Source: Authors. 


\subsection{2-MIB AND GSM DETERMINATION IN WATER SAMPLES}

For 2-MIB and GSM extraction, solid-phase microextraction (SPME) was employed. The SPME fiber consisted of a fused silica fiber coated externally with a stationary phase of polydimethylsiloxane/dimethyl benzene (PDMS/DVB) (SULPECO brand). A Shimadzu PALM 5000 auto sampling system was coupled to gas chromatography/mass spectrometry (GC/MS, QP2010plus) equipment at $70^{\circ} \mathrm{C}$ and with an agitation of $500 \mathrm{rpm}$ for $5 \mathrm{~min}$. We used a stirring cycle of $10 \mathrm{~s}$ with a pause of $5 \mathrm{~s}$ (intervals) (BERLT et al., 2020).

Following Saito and collaborators (2008), the PDMS/DVB fiber exposure was $10 \mathrm{~min}$, accompanied by the stirring cycle described above. For reproducibility, $10 \mathrm{~mL}$ of water was collected in a headspace sampling flask with $3 \mathrm{~g}$ of sodium chloride. All samples were collected in triplicates and injected in triplicate $(n=9)$.

GC/MS separation was performed with a capillary column of polydimethylsiloxane with $5 \%$ phenyl (ZB5ms) (30 m x $0.25 \mathrm{~mm}, 0.25 \mu \mathrm{m}$ film thickness). The splitless injection mode was used at $260^{\circ} \mathrm{C}$, with an initial column temperature of $70^{\circ} \mathrm{C}$ for $1 \mathrm{~min}$, increasing at a rate of $25^{\circ} \mathrm{C} \mathrm{min} \mathrm{mi}^{-1}$ to $260^{\circ} \mathrm{C}$ and remaining for $3 \mathrm{~min}$ (with a helium mobile phase used with $1 \mathrm{~mL} \mathrm{~min}^{-1}$ of flow). The detector conditions were set to $70 \mathrm{eV}$ in scanning mode (SCAN), and selected ion monitoring (SIM) was done for the selected mass/charge ratios (m/z) of 95 and 112 for 2-MIB and GSM, respectively (BERLT et al., 2020).

The linearity of the analytical curve for both analytes was verified through the determination coefficient, which had values above 0.999 . The limit of detection (LOD) and limit of quantification (LOQ) were $0.9 \mathrm{ng} \mathrm{L}^{-1}$ and $3 \mathrm{ng} \mathrm{L}^{-1}$, respectively.

\section{RESULTS AND DISCUSSION}

\subsection{EXPLORATORY EVALUATION OF THE MONITORING OF GSM AND 2-MIB}

Initially, the monitoring of 2-MIB and GSM at six points in Dourado Lake was carried out in 2017 and 2018 to visualize the points that present the highest incidence of these compounds. As shown by Table 1, all the samples contained a low concentration of 2-MIB and GSM. Overall, collection points did not show significant differences $(p>0.05)$ for the evaluated months, except for GSM at the points P5 and P6 in January of 2018 ( $p<0.05)$ in the water exit point in the lake.

Winds and their dynamics can modify water body behavior. During the exploratory phase, the wind direction caused algae and microalgae biomass to accumulate near the water catchment (water exit point). During this period, the winds changed direction in a counterclockwise direction ( $\mathrm{N}$ to $\mathrm{W}$ to $\mathrm{S}$ to $E$ ), making the accumulation of algae at the lake's outlet increase during HAB episodes (cleaning the water surface at the entrance and accumulating at the outlet). Average registered wind speeds showed maximum wind speeds (gusts) of $0.0-4.8 \mathrm{~km} \mathrm{~h}^{-1}$. Wind directions for the 30 minutes before sample collection took place were observed from the university's weather station (demonstrating variability). Wind changes potentially influenced the results obtained concerning the presence of 2-MIB and GSM, although there is not a visible correlation. 
Table 1 - Results of monitoring the concentrations of 2-MIB and GSM in the first period (summer 2017/2018)

\begin{tabular}{|c|c|c|c|}
\hline Month/Year & Collection point & 2-MIB (ng L-1) & GSM (ng L-1) \\
\hline \multirow{6}{*}{ Jan/2017 } & P1 & 3.77 & 18.89 \\
\hline & P2 & 5.10 & 6.22 \\
\hline & P3 & 4.40 & 15.84 \\
\hline & P4 & 3.07 & 26.18 \\
\hline & P5 & 3.98 & 452.36 \\
\hline & P6 & 3.28 & 707.04 \\
\hline \multirow{6}{*}{ Feb/2017 } & P1 & 27.90 & 14.84 \\
\hline & P2 & 4.01 & $<\mathrm{LOQ}$ \\
\hline & P3 & 2.51 & 14.32 \\
\hline & P4 & 2.76 & 44.49 \\
\hline & P5 & n.d. & 38.90 \\
\hline & P6 & n.d. & 29.97 \\
\hline \multirow{6}{*}{ Mar/2017 } & P1 & 9.17 & 24.78 \\
\hline & P2 & 21.79 & n.d. \\
\hline & P3 & 35.35 & 16.37 \\
\hline & P4 & n.d. & 15.14 \\
\hline & P5 & 41.78 & 48.75 \\
\hline & P6 & 32.17 & 13.57 \\
\hline \multirow{6}{*}{ Dec/2017 } & P1 & $<\mathrm{LOQ}$ & $<\mathrm{LOQ}$ \\
\hline & P2 & 7.05 & $<\mathrm{LOQ}$ \\
\hline & P3 & $<L O Q$ & $<\mathrm{LOQ}$ \\
\hline & P4 & $<\mathrm{LOQ}$ & n.d. \\
\hline & P5 & $<\mathrm{LOQ}$ & $<\mathrm{LOQ}$ \\
\hline & P6 & $<\mathrm{LOQ}$ & n.d. \\
\hline \multirow{6}{*}{ Jan/2018 } & P1 & $<\mathrm{LOQ}$ & $<\mathrm{LOQ}$ \\
\hline & P2 & 10.82 & $<\mathrm{LOQ}$ \\
\hline & P3 & 6.81 & $<\mathrm{LOQ}$ \\
\hline & P4 & 7.57 & $<\mathrm{LOQ}$ \\
\hline & P5 & 7.56 & 7.39 \\
\hline & P6 & $<\mathrm{LOQ}$ & $<\mathrm{LOQ}$ \\
\hline
\end{tabular}

LOQ: Limit of quantification; n.d.: Not detected

Source: Research data. 
Although Cyanobacteria influence the appearance of these metabolites (2-MIB and GSM) and reports show linkage between their presence in the water bodies and the presence of these organisms (HATHURUSINGHA; DAVEY, 2014; HATHURUSINGHA; DAVEY, 2016; LI et al., 2019). Asquith and collaborators (2018) explained that bacterial species like Streptomyces (commonly found in soil) could contribute to the development and presence of molecules related to taste and odor variations. These species are capable of increasing the production of metabolites when there are low water levels (exposed soil) and the nutrients/conditions that are necessary for them to grow are available. The produced metabolites are later carried to various water bodies by the rain.

In the results significant differences appeared when correlating 2-MIB and GSM values. According Xuwei and collaborators (2019) which could be related to microbes living in the environment and emitting signal molecules due to specific biotic and abiotic environmental factors. Examples of this are Anabaena (a GSM producer), Planktothrix (a producer of 2-MIB), and Microcystis and Synedraproducers of both metabolites simultaneously (LI et al., 2007).

According to Sugiura and collaborators (2004), abiotic factors related to the production of 2-MIB include temperature, silicic acid, and chemical oxygen demand (COD). Factors related to GSM production include dissolved oxygen (DO), chemical oxygen demand (COD), and total phosphorus. Xuwei and collaborators (2019) report the correlation of the luminosity parameters $\mathrm{Cu}^{2+}, \mathrm{PO}_{4}{ }^{3-}-\mathrm{P}, \mathrm{NH}_{4}^{+}-\mathrm{N}$, and $\mathrm{NO}_{3}^{-}-\mathrm{N}$ induced GSM production.

In January 2017, there was a high GSM value at the water exit point (452.36 ng L-1). In January 2018, these molecules had a detected concentration of $7.39 \mathrm{ng} \mathrm{L}^{-1}$ at the same collection point. Therefore, these results show that occurrences of HABs can be strongly related to a large available nutrient.

\subsection{SEASONAL EVALUATION OF GSM AND 2-MIB}

The experimental phase (second stage) started during the summer of 2019 and focused on assessing the seasonality of HAB events in Dourado Lake. Figure 2 shows the concentrations of GSM and 2-MIB in the samples, which were collected every 15 days for 12 months. Proportions of the molecule presence of GSM and 2-MIB varied, indicating that the biota responsible for the emission of these metabolites changes in the water. Although not analyzed, Actinobacteria, Cyanobacteria, and Proteobacteria produce these metabolites (WATSON, 2003). Cyanobacteria generate the majority of GSM and 2-MIB present in aquatic environments (JUTTNER; WATSON, 2007; WATSON et al., 2008; WINSTON et al., 2014). Still, Actinobacteria dominate the production of GSM and 2-MIB that are present in soil (ZAITLIN; WATSON, 2006). Oscillatoria, Anabaena, Aphanizomenon and Phormidium are common genera in HAB episodes (ORTENBERG; TELSCH, 2003), and their presence could be related to the growth conditions favored by these species (WATSON et al., 2000; SUURNÄKKI et al., 2015; XUWEI et al., 2019). 
Figure 2 - Variables evaluated during Dourado Lake monitoring of 2019: A) -Temperature, Solar radiation, rain, GSM (ng L-1), and B) 2-MIB (ng L-1) concentrations

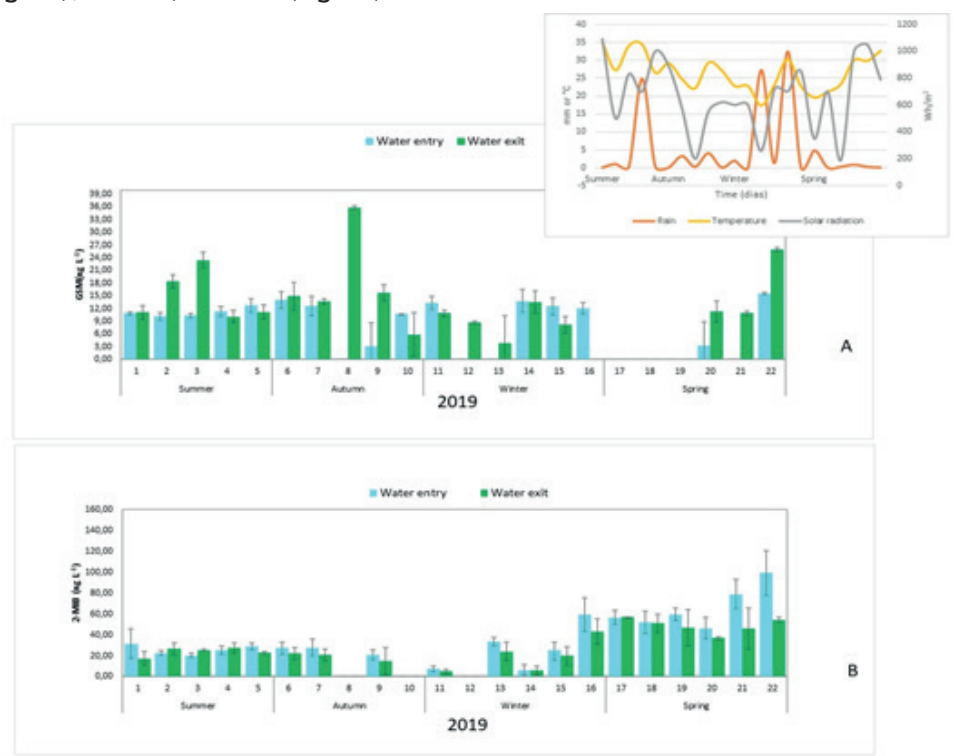

Source: Research data.

As shown in Figure 2, the concentrations of 2-MIB were higher at the entry point, whereas higher concentrations of GSM appeared at the exit point. Association of these results with a higher occurrence of 2-MIB in sediments at the inlet point presents the possibility of a silted environment. The increase of GSM at the exit point occurred because the collection of samples occurred in the water column (ORTENBERG; TELSCH, 2003) supported by the difference in the water column between the entrance and the catchment (the deepest point) of water. The entry point of the lake's water presents there sedimentation of suspended organic and inorganic matter, benefiting the development of organisms in a shallow and sedimented environment (GOHARROKHI et al., 2021). At the catchment point (where the water column is larger), this process is different, benefiting the development of other organisms on the water surface. The observed color of the water reservoir changes from the center to its discharge point due to sedimentation of the suspended material, which is abundant at the entrance (FIGURE 1).

Registered low values (16-19) of 2-MIB and GSM in periods of high rainfall between was found in samples from winter and spring 2019. These periods accompanied by turbulence in the water could affect the relatively fragile cell wall in organisms like Anabaena and favoring Cyanobacteria by a stable water column (LI et al. 2010). In the Autumn (8), GSM was higher, which can be associated with a cyanobacteria bloom. These data relate to soil preparation times for agriculture upstream of the river.

For 20 years, studies showed that the presence of these molecules ranges from $697-7100 \mathrm{ng} \mathrm{L}^{-1}$ for GSM and 164-1200 ng L $\mathrm{L}^{-1}$ for 2-MIB in lakes in several countries (YAO et al. 2017). Fortunately, these conditions are uncommon and not observed for Dourado Lake during our monitoring periods. 
Regardless of the periods studied, concentrations of GSM and 2-MIB that were perceptible to the human palate, with higher amounts registered during the hot seasons, as shown in the molecule concentration/radiation and intensity/temperature correlations presented in Table 2 (although there were not visible $\mathrm{HAB}$ events during 2019 in the lake). Such climatic factors are fundamental and can be associated with $\mathrm{pH}$ and $\mathrm{N}, \mathrm{P}$, and $\mathrm{C}$ content in water to HABs episodes (ZAITLIN; WATSON, 2006; WINSTON et al., 2014; PADEDDA et al., 2017).

Table 2 - Data correlation of GSM and 2-MIB concentration with climatic factors

\begin{tabular}{ccc}
\hline & \multicolumn{2}{c}{ Data correlation } \\
\cline { 2 - 3 } Climatic factors* & 2-MIB $\left(\mathrm{ng} \mathrm{L}^{-1}\right)$ & GSM $\left(\mathrm{ng} \mathrm{L}^{-1}\right)$ \\
\hline Temperature $\left({ }^{\circ} \mathrm{C}\right)$ & 0.036 & 0.347 \\
Solar radiation $\left(\mathrm{W} \mathrm{m}^{-2}\right)$ & 0.150 & 0.099 \\
Precipitation $(\mathrm{mm})$ & -0.382 & 0.046 \\
\hline
\end{tabular}

*Average over the 15 days before the sampling.

Source: Research data.

Significant differences appeared among GSM and temperature (correlation), showing that higher temperature increases the possibility of increasing GSM. On the contrary, 2-MIB decreases with increasing precipitation.

According to Winston and collaborators (2014), Cyanobacteria's dominance in cHABs increases during droughts/low precipitation periods, and it is also influenced by flow rate and changes in temperatures. Our data showed that 2-MIB/GSM values remained constant during periods of high temperatures and became low or undetectable during cold periods, supporting a positive correlation of the production of these substances with solar radiation and temperature intensity values. Unlike what is described above, summer 2017 had values below the perception threshold, which is related to the low rainfall during that period. Martini and collaborators (2019) highlighted that water nutrients may increase after rain due to the leaching of crops near the river that supplies water to the reservoir.

Additionally, the presence of nutrients (fertilizers) in water is due to land preparation for tobacco planting upstream of the lake, the main agricultural activity in the region (CARVALHO et al., 2019; LOBO et al., 2020), causes HABs in July and August, an effect not considered. According to Paerl and collaborators (2016), the rain also interferes directly with the eutrophication of the water's surface.

Phoslock $^{\otimes}$ (Phoslock Water Solutions Ltd.) was applied to the lake to control HAB episodes in 2015 (MARTINI et al., 2019); it is a clay adsorbent (bentonite modified with lanthanum) that captures the phosphorus molecules present in the water column, interfering in the sediment/water interface to prevent the anoxic release of phosphorus (MOOS et al., 2014). After treatment with Phoslock ${ }^{\circledR}$, episodes of HABs were reported by the local population, who detected their presence through the taste and odor of the treated water. Newspaper reports tracked the events associated with these molecules before and after treatment, showing that the additives used as solutions did not solve the issue (FIGURE 3). Sporadic 
HAB episodes have occurred; still, the citizens' perception of these water molecules through odor and taste and the collected data of this study show that there have been more events than those recorded.

Figure 3 - Chronological newspaper reports about registered HAB episodes in Dourado Lake from 2015 to 2019

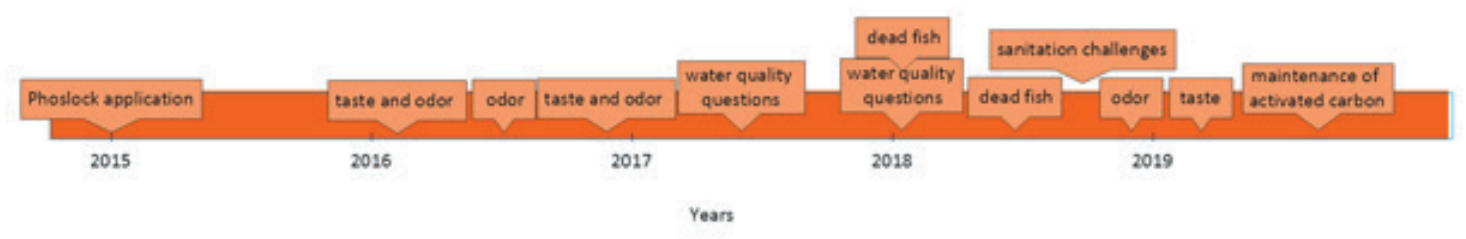

Source: Research data.

Management of the water quality of reservoirs like the one discussed here follows the same parameters and standards globally (NGUYEN et al., 2017; HASANZADEH et al., 2020). We can see a consistent trend of treating the water reservoir and not the source feeding it (the river), leading to the temporary mitigation of problems and not to any control over the source. Dourado Lake serves as a model for treatment, and through time, it has been proved that techniques like the addition of Phoslock ${ }^{\circledR}$ to the water do not totally solve the problem of the presence of GSM and 2-MIB. Besides monitoring and the application of additives to counteract the undesired smell and flavor detected by the public, new approaches include the education and remuneration of local citizens living near or at the margins of the river as a way to prevent the leaching or pouring of detrimental products that could lead to the development of HABs into the lake. As a consequence of these initiatives during summer 2019/2020, environmental issues (drought) encountered in the region were easily managed through the education of and payment to the citizens living near the river margins, which turned them into the protectors of this water resource.

Therefore, the smell and flavor detected by the public is minimized with actions associated to permanent environmental education. The compensation programs are called "Payments for environmental services" as in the Arroio Andréas Basin case in Vera Cruz, RS, with excellent conservation results (DELEVATI et al., 2018).

\section{CONCLUSION}

The determination of the concentrations of 2-MIB and GSM through water monitoring of Dourado Lake indicated that the detected concentrations were high enough for the public to perceive them all year round. Summer was the season with the highest nutrient concentration and biological diversity. Taste and odor characteristics come from the water of the Pardinho River (detected at the water entry point), showing the importance of the correct management of the hydrographic basin and also 
showing that improvement in the lake may not be the most appropriate solution. Remediation and prevention actions may be necessary along the river.

\section{ACKNOWLEDGEMENTS}

To Coordenação de Aperfeiçoamento de Pessoal de Nível Superior (CAPES) (financial code 001) and Conselho Nacional de Desenvolvimento Científico e Tecnológico (CNPq) (protocol 310228/20190 and 306279/2017-7) by research support and city hall of Santa Cruz do Sul by help us in the water sampling at Dourado Lake.

\section{REFERENCES}

ASQUITH, E.C. et al. Distribution, abundance and activity of geosmin and 2-methylisoborneolproducing Streptomyces in drinking water reservoirs. Water Res., v. 145, p. 30-38, 2018.

BERLT, M.M.G. et al. Comparative assessment of the degradation of 2-methylisoborneol and geosmin in freshwater using advanced oxidation processes. Environ Technol., p. 1-8, 2020.

BRISTOW, R.L. et al. An extensive review of the extraction techniques and detection methods for the taste and odour compound geosmin (trans-1, 10-dimethyl-trans-9-decalol) in water. TrAC Trend Anal Chem., v. 110, p. 233-248, 2019.

CARMICHAEL, W.W.; BOYER, G.L. Health impacts from cyanobacteria harmful algae blooms: Implications for the North American Great Lakes. Harmful Algae, v. 54, p. 194-212, 2016.

CARVALHO, F.S. et al. Life cycle assessment of biodiesel production from solaris seed tobacco. J Clean Prod., v. 230, p. 1085-1095, 2019.

DELEVATI, D.M. et al. Histórico do programa de pagamento por serviços ambientais (PSA) na Bacia hidrográfica do arroio Andréas, RS, Brasil. Cad Pesquisa, v. 30, n. 1, p. 29-40, 2018.

GOHARROKHI, M. et al. Sedimentation dynamics within a large shallow lake and its role in sediment transport in a continental-scale watershed. J Great Lakes Res., v. 47, n. 3, p. 725-740, 2021.

HASANZADEH, S. K. et al. A fuzzy equilibrium strategy for sustainable water quality management in river-reservoir system. J Hydrol., v. 586, p. 124892, 2020. 
HATHURUSINGHA, P.I.; DAVEY, K.R. Chemical taste taint accumulation in RAS farmed fish - A Fr 13 risk assessment demonstrated with geosmin (GSM) and 2-methylisoborneol (MIB) in barramundi (Lates calcarifer). Food Control., v. 60, p. 309-319, 2016.

HATHURUSINGHA, P.I.; DAVEY, K.R.A predictive model for taste taint accumulation in Recirculating Aquaculture Systems (RAS) farmed-fish - demonstrated with geosmin (GSM) and 2-methylisoborneol (MIB). Ecol Model., v. 291, p. 242-249, 2014.

JOHN, N. et al. An improved method for PCR-based detection and routine monitoring of geosminproducing cyanobacterial blooms. Water Res., v. 136, p. 34-40, 2018.

JUTTNER, F.; WATSON, S. B. Biochemical and ecological control of geosmin and 2-methylisoborneol in source waters. Appl Environ Microbiol., v. 73, n. 14, p. 4395-4406, 2007.

KIM, T. K. et al. Degradation mechanisms of geosmin and 2-MIB during UV pho;tolysis and UV/ chlorine reactions. Chemosphere, v. 162, p. 157-164, 2016.

KUTSCHERA, K. et al. Photoinitiated oxidation of geosmin and 2-methylisoborneol by irradiation with $254 \mathrm{~nm}$ and $185 \mathrm{~nm}$ UV light. Water Res., v. 43, n. 8, p. 2224-2232, 2009.

LI, L. et al. Annual dynamics and origins of the odorous compounds in the pilot experimental area of Lake Dianchi, China. Water Sci Technol., v. 55, n. 5, p. 43-50, 2007.

LI, L. et al. Variation and removal of 2-MIB in full-scale treatment plants with source water from Lake Tai, China. Water Res., v. 162, p. 180-189, 2019.

LI, Z. et al. Cyanobacterial population and harmful metabolites dynamics during a bloom in Yanghe Reservoir, North China. Harmful Algae, v. 9, n. 5, p. 481-488, 2010.

LIU, S. et al. Parameters influencing elimination of geosmin and 2-methylisoborneol by K2Fe04. Sep Purif Technol., v. 182, p. 128-133, 2017.

LOBO, E. A. et al. Potential for bifenthrin removal using microalgae from a natural source. Water Sci Technol., v. 82, n. 6, p. 1131-1141, 2020.

LOBO, E.A. et al. Utilização de um protocolo de avaliação rápida de impacto ambiental em sistemas lóticos do Sul do Brasil. Cad Pesq Biol., v. 23, n. 1, p. 15, 2011.

MARTINI, F.A. et al. Periphytic biomass composition and exploitation from algae turf scrubber system. SN Appl Sci., v. 1, n. 7, p. 765, 2019. 
MOOS, M.T. et al. Establishing ecological reference conditions and tracking post-application effectiveness of lanthanum-saturated bentonite clay (Phoslock ${ }^{\circledR}$ ) for reducing phosphorus in aquatic systems: An applied paleolimnological approach. J Environ Manag., v. 141, p. 77-85, 2014.

NGUYEN, H. H.; RECKNAGEL,F.; MEYER, W.; FRIZENSCHAF, J.; SHRESTHA, M. K. Modelling the impacts of altered management practices, land use and climate changes on the water quality of the Millbrook catchment-reservoir system in South Australia. J Environ Manag., v. 202, n. Pt 1, p. 1-11, 2017.

ORTENBERG, E.; TELSCH, B. Taste and odour problems in potable water. In: Mara, D.; Horan, N.J. (Ed.) Handbook of Water and Wastewater Microbiology. London: Academic Press, 2003.

PADEDDA, B.M. et al. Consequences of eutrophication in the management of water resources in Mediterranean reservoirs: A case study of Lake Cedrino (Sardinia, Italy). Global Ecol Conserv., v. 12, p. 21-35, 2017.

PAERL, H.W. et al. Mitigating cyanobacterial harmful algal blooms in aquatic ecosystems impacted by climate change and anthropogenic nutrients. Harmful Algae, v. 54, p. 213-222, 2016.

PALMEIRA, A. et al. Physicochemical and microbiological quality of the public water supply in 38 cities from the midwest region of the State of São Paulo, Brazil. Water Environ Res., v. 91, n. 8, p. 805-812, 2019.

PERKINS, R. G. et al. Managing taste and odour metabolite production in drinking water reservoirs: The importance of ammonium as a key nutrient trigger. J Environ Manag., v. 244, p. 276-284, 2019.

SAITO, K. et al. Determination of musty odorants, 2-methylisoborneol and geosmin, in environmental water by headspace solid-phase microextraction and gas chromatography--mass spectrometry. J Chromatogr A, v. 1186, n. 1-2, p. 434-437, 2008.

SRINIVASAN, R.; SORIAL, G. A. Treatment of taste and odor causing compounds 2-methyl isoborneol and geosmin in drinking water: a critical review. J Environ Sci (China) v. 23, n. 1, p. 1-13, 2011.

SUGIURA, N. et al. Assessment for the complicated occurrence of nuisance odours from phytoplankton and environmental factors in a eutrophic lake. Lake Reserv Res Manag., v. 9, n. 34, p. 195-201, 2004.

SUURNÄKKI, S. et al. Identification of geosmin and 2-methylisoborneol in cyanobacteria and molecular detection methods for the producers of these compounds. Water Res., v. 68, p. 56-66, 2015. 
VON SPERLING, E. et al. Comparative eutrophication development in two Brazilian water supply reservoirs with respect to nutrient concentrations and bacteria growth. Desalination, v. 226, n. 1-3, p. 169-174, 2008.

WATSON, S. B. Cyanobacterial and eukaryotic algal odour compounds: signals or by-products? A review of their biological activity. Phycol., v. 42, n. 4, p. 332-350, 2003.

WATSON, S.B. et al. Quantitative analysis of trace levels of geosmin and MIB in source and drinking water using headspace SPME. Water Res., v. 34, n. 10, p. 2818-2828, 2000.

WINSTON, B. et al. The influence of rainfall on taste and odor production in a south-central USA reservoir. Freshw Sci., v. 33, n. 3, p. 755-764, 2014.

WATSON, S.B. et al. Biochemistry and genetics of taste- and odor-producing cyanobacteria. Harmful Algae, v. 54, p. 112-127, 2016.

WATSON, S.B. et al. Taste and odour and cyanobacterial toxins: impairment, prediction, and management in the Great Lakes. Can J Fish Aquatic Sci., v. 65, n. 8, p. 1779-1796, 2008.

XUWEI, D. et al. The relationships between odors and environmental factors at bloom and nonbloom area in Lake Taihu, China. Chemosphere, v. 218, p. 569-576, 2019.

YAO, W. et al. Comparison of methylisoborneol and geosmin abatement in surface water by conventional ozonation and an electro-peroxone process. Water Res., v. 108, p. 373-382, 2017.

ZAITLIN, B.; WATSON, S.B. Actinomycetes in relation to taste and odour in drinking water: myths, tenets and truths. Water Res., v. 40, n. 9, p. 1741-1753, 2006.

ZAT, M.; BENETTI, A. D. Remoção dos compostos odoríferos geosmina e 2-metilisoborneol de águas de abastecimento através de processos de aeração em cascata, dessorção por ar e nanofiltração.

Eng Sanit Amb., v. 16, n. 4, p. 353-360, 2011. 
1 Master degree in Environmental Technology; Environmental Technology Postgraduate Program, University of Santa Cruz do Sul, Santa Cruz do Sul, RS, Brazil.

Email: helena.wilges92@gmail.com

2 Doctor in Chemistry; Environmental Technology Postgraduate Program, University of Santa Cruz do Sul, Santa Cruz do Sul, RS, Brazil. Email: adilson@unisc.br

3 Doctor in Engineering; Environmental Technology Postgraduate Program, University of Santa Cruz do Sul, Santa Cruz do Sul, RS, Brazil. Email: enio@unisc.br

4 Master degree in Environmental Technology; Environmental Technology Postgraduate Program, University of Santa Cruz do Sul, Santa Cruz do Sul, RS, Brazil.

Email: mariana_berlt@hotmail.com

5 Doctoral student; Environmental Technology Postgraduate Program, University of Santa Cruz do Sul, Santa Cruz do Sul, RS, Brazil. Email: jocelenesoares@unisc.br

6 Doctor in Agronomy, University of Santa Cruz do Sul, Santa Cruz do Sul, RS, Brazil. Email: hoppe@unisc.br

7 Doctor in Chemistry; Environmental Technology Postgraduate Program, University of Santa Cruz do Sul, Santa Cruz do Sul, RS, Brazil. Email: tielem@unisc.br

8 Doctor in Science; Environmental Technology Postgraduate Program, University of Santa Cruz do Sul, Santa Cruz do Sul, RS, Brazil. Email: andmari.sb@gmail.com

9 Doctor in Chemistry; Environmental Technology Postgraduate Program, University of Santa Cruz do Sul, Santa Cruz do Sul, RS, Brazil. Email: rosana@unisc.br
Recebido em: 30 de Junho de 2021

Avaliado em: 29 de Julho de 2021

Aceito em: 29 de Julho de 2021
A autenticidade desse artigo pode ser conferida no site https://periodicos. set.edu.br

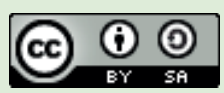

Este artigo é licenciado na modalidade acesso abertosob a Atribuição-Compartilhalgual CC BY-SA
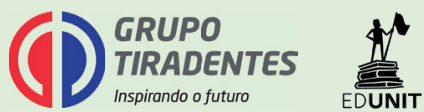